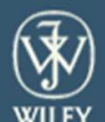

Geoarchaeology

\title{
Geoarchaeological study of abandoned Roman urban and suburban contexts: cases from central Adriatic Italy
}

\begin{tabular}{|c|c|}
\hline Journal: & Geoarchaeology \\
\hline Manuscript ID & GEO-15-119.R1 \\
\hline Wiley - Manuscript type: & Research Article \\
\hline Date Submitted by the Author: & $n / a$ \\
\hline Complete List of Authors: & $\begin{array}{l}\text { Vermeulen, Frank; Ghent University, Archaeology } \\
\text { Pincé, Possum; Ghent University } \\
\text { Weekers, Lara; Ghent University } \\
\text { De Dapper, Morgan; Ghent University, Geography }\end{array}$ \\
\hline Keywords: & Geoarchaeology, Abandoned towns, Roman period, Italy \\
\hline
\end{tabular}




\title{
Geoarchaeological study of abandoned Roman urban and suburban contexts: cases from central Adriatic Italy
}

\author{
Frank Vermeulen ${ }^{1}$, Possum Pincé ${ }^{1}$, Lara Weekers ${ }^{1}$, Morgan De Dapper ${ }^{2}$ \\ ${ }^{1}$ Department of Archaeology, Ghent University, Ghent, Belgium \\ ${ }^{2}$ Department of Geography, Ghent University, Ghent, Belgium
}

\begin{abstract}
The Potenza Valley Survey project investigates since 2000 the settlement dynamics in the Central Adriatic Potenza valley, with particular attention to the period from the Iron Age to early Medieval times (900 BC-AD 900). Part of this research focuses on the Roman abandoned towns of Potentia and Trea by performing an integrated, geoarchaeological study of their townscape. This largely noninvasive research consists of remote sensing analysis, geophysical surveys (magnetometry, electrical resistivity and Ground Penetrating Radar) and geomorphological fieldwork such as microtopographic measurements and hand augerings. The chosen techniques depend on the nature of each town and are integrated with more traditionally achieved research data. This paper presents the main interdisciplinary results of these two Roman towns and highlights the importance of obtaining complementary data and performing hand augering as a stratigraphic control of the remote sensing and geophysical results. An insight in the character and layout of the cities, the structural influence on the surrounding area and the human-environment interactions and dynamics through time of both Roman cities could be obtained. Moreover, the results offer guidelines for conservation strategies of these abandoned towns and their suburbium, which are necessary to protect them from present-day threats such as agriculture and tourism.
\end{abstract}

\section{KEY WORDS}

Geoarchaeology, Abandoned towns, Roman period, Italy

\section{INTRODUCTION}

From the 1980s onwards archaeologists working on ancient urban sites started to realize that the systematic application of non-invasive field techniques held out the promise of making a major contribution to our understanding of ancient urbanism. Advancement of knowledge would now not anymore come from the often large and successful towns with almost uninterrupted and full habitation continuity until our time, where archaeological excavations and traditional topographic work in urban environments typically centered on the more monumental or visible structures. But especially the category of ancient urban sites, which today are partly or often even fully abandoned, now came much more into the picture. This happened especially in the Mediterranean area where preservation conditions are best, a multitude of very well built classical cities existed, and where many urban centers show settlement discontinuity in Medieval or modern times. Spurred by seminal projects such as the study of Boeotian towns by Bintliff and Snodgrass (1985, 1988), as well as by the refinement of geophysical techniques and aerial photography that could 
be used for the fine-grained analysis required to bring out details of urban layout (Barber, 2011; Bourgeois \& Meganck, 2005; Doneus, 2004; Guaitoli, 2003; Scollar, Tabbagh, Hesse, \& Herzog, 1990), a new age of urban studies in the field emerged. Partly helped by the power of GIStechnology and other techniques currently used in the geosciences this evolution created, since the turn of the millennium, a boom in the non-invasive destructive survey of urban sites, especially of the classical Greek and Roman periods (Christie, 2012; Johnson \& Millett, 2012; Vermeulen, Burgers, et al., 2012). This has also led to a revolution in how archaeologists approach urban sites, with survey techniques being used increasingly often to generate a plan of a town site prior to excavation, while cultural heritage management authorities have also benefited from this approach, with urban surveys providing them with a very effective tool for gauging the degree of archaeological survival on major urban sites in their care and choosing appropriate conservation strategies.

Most recently, research has begun to reveal the advantages of intensively integrating a range of different non-destructive techniques on urban sites, choosing those suites that are most appropriate for the nature of the town in question (Corsi, Slapšak, \& Vermeulen, 2013), such as is well demonstrated at several ancient urban sites (Vermeulen, 2013a, 2013b). The variety of techniques can be quite impressive, such as the application of different geophysical instruments (for georadar, magnetometer or earth resistance survey, etc.), different aerial photography approaches (such as flying with traditional airplanes, drones or balloons, or using multispectral techniques of photography), LiDAR scanning of the sites, and other geomorphological and geomatic approaches (augering, erosion modelling, DEM production etc.). Therefore, the concept of integrated, non-invasive multi-method survey relates to a much wider range of techniques, and the overall methodology envisages a reasoned deployment of them all, or of a choice of them for systematic data acquisition at the site studied, by testing, sampling or total coverage (Vermeulen, 2013a, 2013b).

But the picture tends to be complex, and the tools to address this complexity are normally diverse and adapted to each case under study. The approaches depend on a variety of factors specific to the local area such as the natural setting and geomorphological changes through time, the scale of the site and its depth of monumentality and stratigraphy, the post-urban population presences and needs, the degree of Medieval to modern efforts to rob or reclaim the terrain and its materials, and sometimes earlier archaeological intrusions. Furthermore, some sites are far more visible or more accessible than others, while some have landmarks which guide readings as to what is missing and some have been more damaged than others (Christie, 2012, p. 285). So flexibility rather than uniformity will be the rule, and that requires a thorough understanding of the options at hand and of the problems we can realistically explore by non-invasive geoarchaeology.

In this paper, we wish to briefly present two case studies in an Italian context where non-invasive survey approaches to study ancient abandoned towns have met with good success. The examples from the towns of Potentia and Trea, both located in the central Adriatic region of Marche (Figure 1), illustrate some of the research options at hand and highlight the potential of the 
interdisciplinary approach inherent to the geoarchaeology of Classical Antiquity, as already advocated by two of us some 15 years ago (Vermeulen \& De Dapper, 2000). At the same time they lay bare some of the typical problems of such fieldwork in past urban contexts, as well as the limits of the possible at the current stage of methodological development, while at the same time offering some avenues for a more soil science based type of urban survey.

Figure 1 Location of the study area.

\section{A SUITE OF APPROACHES FOR URBAN SURVEY}

Intensive fieldwork and remote sensing operations at both chosen urban sites started in 2000, as part of the archaeological Potenza Valley Survey project, which focuses on the longue durée settlement dynamics in a typical central Italian valley between the Apennines and the Adriatic sea. Over the years this long term project gave special priority to the intensive study of four partly or fully abandoned Roman town sites and their immediate hinterland, equally dispersed along the valley corridor of the River Potenza. Potentia, a newly founded colonial city of Roman citizens (foundation date $184 \mathrm{BC}$ ) situated in the valley bottom at the river mouth, and Trea, an urban settlement that had since c. 50 BC gradually developed and is located on a small plateau near the central part of the valley, have been studied most elaborately since 2004. Both sites had known only very punctual topographic research before these new investigations, while the few excavations done there had remained very punctual and had not provided insight in such crucial matters as: the exact extent of the urban areas, their street grids and public structures, their housing organization, the character and location of suburban sectors, and the structural impact on the surrounding landscape of roads, cemeteries, field systems and economic exploitation areas. To reveal these elements of the Roman urbanization system in the area, and to answer a whole set of related historical and archaeological questions, a fundamentally integrated new approach was needed. The most diagnostic of these operations comprised the following steps.

The first part of the intensive study of both urban settlements through time, between the Roman Late Republic and their gradual abandonment in the course of the Early Middle Ages $\left(7^{\text {th }}-9^{\text {th }}\right.$ centuries AD), involved the evaluation and re-study of earlier field observations and material collections, and the organization of new and systematic intra-site field walking to collect artifact scatters brought to the surface. As both sites are today still mostly in use as agricultural land these surface concentrations are in part the result of ploughing activities. The field walking provided diachronically subdivided distribution maps of artifact densities and of qualities of archaeological material, which allowed to assess among others certain spatial evolutions of the sites between their Roman and Early Medieval history, functional zoning during the life of the cities (workshops, houses, cemeteries, public buildings...), and the archaeological and geomorphological erosion factors and post-depositional processes.

A second group of new and old data was acquired from a wide array of remote sensing sources. Throughout the now 15 year old project, detailed and significant knowledge about spatial aspects of the urban and surburban areas could be derived from increasingly available aerial photography 
of both sites and their immediate surrounding landscapes. Among existing imagery, normally taken at higher altitudes for other purposes than archaeology, this is in the first place certain historical photography pre-dating more modern landscape changes, such as the excellent imagery of the coastal area around Potentia by RAF flights at the end of WWII and several other series of aerial photos covering parts of the second half of the last century. Of particular importance for details on buried structures of this coastal town, often visible through crop marks in the covering agricultural vegetation, are also the now widely available and high resolution aerial and satellite views from applications such as Google Earth or Bing, and recently also some good LiDAR imagery from the Italian Ministry of Environment.

The bulk of the remote sensing information for both sites was however acquired via an intensive and long term program of photography flights by the Belgian team, intensively monitoring the local archaeology from different aerial platforms. The spectacular discovery of many buried structures of both towns and their suburban landscapes has over the years allowed a very detailed mapping of a wide range of features bringing exact knowledge of defensive systems, the quasi full street grids, most of the public buildings and monuments (forum, temples, market halls, theatres/amphitheatres, ...), house-plans, cemeteries, etc. The sheer size and character of these Roman population centers and of certain architectural creations, the systematic choice of durable building materials and the sometimes quite impressive impact on the local topography of a place, all contribute well to this present-day vision obtained from the air, even if both town sites have today left almost no traces of their existence above ground. As it was seldom possible to photograph the buried traces totally and during one flight only, it was a crucial part of the monitoring strategy to do regular follow up flights of the area during different seasons and in different weather conditions. This active aerial photography has been applied as well from a "classic" manned aircraft (mostly bi- to four-sitters) as from several low-altitude unmanned platforms (a helikite and a radio-controlled multi-copter drone) (Vermeulen, 2004, 2012; Vermeulen \& Verhoeven, 2004; Vermeulen, Verhoeven, \& Semey, 2005). The remarkable speed and image quality of aerial imagery obtained from such increasingly low-cost solutions make the latter platforms potent instruments for reconnaissance. They have also allowed and stimulated the further exploitation of new imaging techniques, such as close-range near-infrared photography (Verhoeven, 2008, 2012) and near-ultraviolet imaging (Verhoeven \& Schmitt, 2010; Verhoeven, Smet, Poelman, \& Vermeulen, 2009). The now more readily available software solutions to orthorectify these oblique images (e.g. PhotoScan) (Verhoeven, Doneus, Briese, \& Vermeulen, 2012), even in the more undulating middle-Potenza landscape around Trea, has in recent years also facilitated the topographically more exact interpretative mapping needed for this survey method.

As in many surveys of large urban sites elsewhere in the Mediterranean and beyond, the project strategy also comprised the intensive use of geophysical prospections for mapping structural buried features. Because magnetic surveys generally detect most types of archaeological features within Roman urban sites, other geophysical survey techniques are only seldom applied on a 
large scale, as they are more time consuming and hence expensive. However, feature detection through multiple parameters enhances interpretative validity (Neubauer \& Eder-Hinterleitner, 1997; Neubauer, Eder-Hinterleitner, \& Melichar, 2002). In addition, recent developments, such as DGPS equipped multi-instrument platforms and towed arrays, allow relatively rapid collection of more extensive but also more intensive geophysical datasets. It is clear that for the total survey of buried Roman towns sites we need to apply as much as possible all relevant geophysical approaches: so apart from geomagnetic survey, also earth resistance and georadar prospections are used if available and possible, to name but the most effective today. We, therefore, arranged to apply these three methods together to obtain not only an almost full coverage of the formerly inhabited intra-mural areas of our two Potenza valley towns (Potentia: 18 ha, Trea: 12 ha), but also to cross their data in the most productive ways in view of the interpretation of the evidence. This was especially successful on the site of Trea, even if on both sites the high clay composition of the soils caused GPR-results to be very poor (Vermeulen, Slapšak, \& Mlekuž, 2012). Furthermore, a program of covering some of the extra-mural spaces of both sites has also been initiated, including targeted use of a multi-electrode resistivity meter survey for deeper sounding and palaeo-landscape mapping, as covering of the buried Roman and Medieval archaeology by recent deposits proved very disturbing for both aerial and normal geophysical detection.

This brings us to a sequence of field operations that we judge to be crucial in such large scale and non-invasive field operations on the essentially greenfield sites of former Roman towns. They are the more geomatic and specifically geomorphologically based approaches that in association with the archaeological questionnaire form the core of real 'geoarchaeology'. From the onset of the field operations the need was felt to produce a high-resolution Digital Elevation Model (DEM) of the areas under investigation in order to relate the urbanization effort and use of the urban site by the ancients with the physical landscape of the past and today. This is needed not only to contextualize better the underground (and above ground) features detected with aerial and geophysical survey, but also to understand the "phenomenology" of complex sites and landscapes. The DEM is needed not only to support the volumetric and 3D reconstructions, but also to allow spatial analysis with a full understanding of post-depositional processes. DEMs can also play a role when studying the effects of processes affecting the representativeness and conservation of the archaeological record. Furthermore, they may be very useful to assess the reliability of the results of surface surveys and the preservation of archaeological deposits (Martinez del Pozo \& Mayoral Herrera, 2013). For the relative flat bottom-valley site of Potentia the currently still most common method of topographic survey with total station and DGPS proved to be of enough relevance, even if recently available LiDAR data for the area adds a new dimension to the results (see below). For sites with more relevant micro-topography and lying in a more undulating and expressive topographic environment, such as Trea, our excellent and repeated aerial photography allowed for the production of relevant photogrammetric DEM's (Verhoeven, Loenders, Vermeulen, \& Docter, 2009). 
Of the same order of importance, but still somewhat undervalued in many field projects is the insertion of a series of geoarchaeological field operations, which specifically target the deeper palaeo-morphology and a better understanding of the sometimes deeply buried archaeology. Apart from the already mentioned resistivity surveys, which have been very useful to reveal palaeo-channels of the River Potenza and the palaeo-coastline near the colony city of Potentia, especially the use of manual augerings seems adapted for fully integrated ground-truthing of much relevant data from non-invasive survey operations and landscape observations. For the augering survey hand auger equipment of Eijkelkamp $(7 \mathrm{~cm}$ diameter) was used, consisting of an Edelman auger, stony soil auger, spiral auger, soft soil auger, riverside auger, stone catcher, handles, extension rods and bayonet connections. The applied auger depends on the dominant texture of the sediment; in perfect soil conditions the maximum achievable depth of the hand auger is around 15 meters_(Berendsen, 2005). The different soil layers were described based on the texture, color, compaction, boundary characteristics and presence of archaeological material. In what follows we will elaborate a bit more on these geomatic and geomorphological field techniques, which need a constant dialogue between the geoscientists and the archaeologists in the field.

\section{THE URBAN AND WESTERN SUBURBAN SETTING OF POTENTIA}

\subsection{City Layout}

The site of Potentia, situated in the south of the present town of Porto Recanati at a distance of 100 $\mathrm{m}$ from the Adriatic coastline, was discovered in the 1940s. In the following decades several smallscale excavations were performed in and around the town, but it was only in the frame of the PVSproject that the Roman colony and the relation with its environment were fully investigated and a detailed plan of the town was obtained (Vermeulen \& Verhoeven, 2006). Remote sensing analysis, based on oblique aerial, vertical aerial and satellite images, was achieved from 2000 onwards. Part of the obtained images revealed crop and soil marks indicating subsurface archaeological features such as the street network, town walls and traces of large buildings (Vermeulen, Monsieur, et al., 2005; Vermeulen \& Verhoeven, 2006). In addition, several campaigns of grid field walking were done for qualitative and quantitative data acquisition of the subsurface archaeological features (Vermeulen, De Dapper, et al., 2009).

In 2004 and 2005, large scale geophysical surveys were executed to locate the subsurface archaeological relicts detected by remote sensing analysis and grid walking and to identify more details about the city layout (Vermeulen \& Verhoeven, 2006). The positive NNW-SSE oriented anomalies of the magnetic surveys could easily be interpreted as parts of the street grid. A rectangular anomaly in the center of the town, bordered by many linear anomalies, represents the forum square with surrounding shops (tabernae), a portico and several large public buildings, including a Late Republican sanctuary found by previous excavations. In addition, positive anomalies of the city walls and two gates (west and south) could be defined (Vermeulen, 
Monsieur, et al., 2009; Vermeulen \& Verhoeven, 2006) (Figure 2). The magnetic survey was combined with the complementary resistivity technique to gain more information about the nature of the magnetic anomalies. In this way, the street pattern with housing blocks (insulae) of different sizes and several monumental buildings could be identified (Vermeulen \& Verhoeven, 2006). To verify the presence of the western gate assumed by the remote sensing and geophysical surveys, and to uncover its construction and relation with the surrounding area, an excavation was executed between 2007 and 2010 (Vermeulen, De Dapper, et al., 2009; Vermeulen et al., 2011; Vermeulen, Monsieur, et al., 2009).

Figure 2 A reconstruction of the city layout of Potentia based on remote sensing analysis and geophysical prospections.

\subsection{Topographic Setting of the Urban Area}

For the detection of micro-topographical features, a series of total station measurements were taken during field campaigns between 2005 and 2007, and a Digital Elevation Model (hereafter DEM) was created (Vermeulen \& Verhoeven, 2006). The DEM (Figure 3a) shows a slightly higher position of the town, which is due to the presence of an ancient beach ridge on which the town had settled since it offered protection against flooding. At that time, the ancient river course ran immediately south of the city wall, as was well shown by a series of geoarchaeological operations (Goethals, De Dapper, \& Vermeulen, 2009). During the post-Roman period, the beach ridge was cut in the southeast by the Potenza river channel. This phenomenon is mainly visible on the LiDAR DEM (Figure $3 b$ ). It was also present on remote sensing images and could be verified by hand augerings and geoelectrical resistivity profiles. The forum square in the center of Potentia (Figure 3a and b, black box) appears to be lower than the other parts of the town. This and other micro-topographical differences are more visible in the DEM obtained from total station measurements than in the LiDAR DEM. It can also be observed that the area west of Potentia lies more or less at the same height as the town center. Hand augerings showed this is mainly due to the deposition of clayey and silty sediments during flooding in the $14^{\text {th }}$ and $15^{\text {th }}$ century AD. Hence, this area was lower and more sensitive to flooding in Roman times (Goethals et al., 2009).

Figure 3 Digital Elevation Model (DEM) of Potentia based on micro-topographical measurements from the PVScampaigns (a) and the DEM of LiDAR data from the Italian Ministery of Environment, created in 2009 (b).

The geomorphological evolution of the area is very efficiently defined by hand augering (HA), a rather simple and inexpensive technique. The deepest layer could be reached by the use of many extension rods and represented a beach deposit on which the beach ridge was formed (see below Figure 6, hand augering 1). The formation of this beach ridge must have occurred between 1500 and $300 \mathrm{BC}$ and was a consequence of the deforestation during the Bronze and Iron Age (circa 2200-300 BC), which caused a higher sediment load in the Potenza river (Coltorti, 1989, 1997). The beach ridge has a steep seaward and more gentle landward slope. Several augerings were carried out to reconstruct the landward slope of the beach ridge on top of which the Roman town 
of Potentia was built (boreholes 1, 9, 14 and 18) (Vermeulen et al., 2013). Based on augerings 9, 14 and 18 (Figure 4), the inland slope of the beach ridge could be calculated. From augering 9 to 14 , the landward slope is $2.2 \%$. The beach ridge created a natural barrier inducing the formation of a lagoon behind the ridge. In time, sedimentation took place transforming the area during the first centuries of Roman occupation (circa 200 BC - 200 AD) from a marshy to dryer area with seasonal floods. This phenomenon was testified by thinly laminated silty sediments. The upper sedimentological units consist of alluvial material from post-Roman periods. The aggradation of the topsoil was stimulated by increasing deforestation for agriculture and cattle raising during the late and post-medieval period causing an increased erosion on the surrounding hillslopes (Coltorti, 1991; Goethals, De Dapper, \& Vermeulen, 2005).

\subsection{Subsurface Archaeological Features in the Western Suburbium}

Additional crop and soil marks were detected outside the formerly walled area on oblique aerial photographs and satellite images during the campaigns from 2004 to 2012 . These traces revealed the presence of three Roman roads entering Potentia at its northern, western and southern gates. The road coming from Rome and entering the town in the west is the decumanus maximus of the town. Extra Muros, this road connected Potentia with its regularly divided field system (centuriatio) in the valley bottom and with the nearby inland Roman town of Ricina (Vermeulen et al., 2009). Crop marks of subsurface structures along both sides of this road are visible on the images. These structures are interpreted as Roman funerary monuments based on former excavations and research along the north-south oriented coastal road (cardo maximus extra muros) leaving Potentia from the northern and southern gates, and by the presence of a still standing funerary monument along the decumanus maximus extra muros (hereafter $\mathrm{dmem}$ ) at the site of Torraccio (Figure 2), about $500 \mathrm{~m}$ west of the western gate (Vermeulen, De Dapper, et al., 2012; Vermeulen, De Dapper, et al., 2009; Vermeulen \& Verhoeven, 2006).

To achieve more detailed information about the extension of the funerary area and to locate and map the sub-surface archaeological relicts, a geomagnetic survey was done in this western sector (Vermeulen, De Dapper, et al., 2012; Vermeulen, De Dapper, et al., 2009). This survey detected $250 \mathrm{~m}$ long linear traces of the $d m e m$, before they are blurred by the presence of buried metal pipes causing large dipole anomalies (Figure 4, yellow zone ). Along both sides of the road, small, positive magnetic anomalies were detected, which coincide with the crop marks from the aerial images and thus most likely represent archaeological relicts (Figure 4, blue marks). In addition, anomalies of modern structures and of a geological or geomorphological nature occurred (Vermeulen, De Dapper, et al., 2012).

Figure 4 Results and interpretation of the geomagnetic surveys (2012-2013) by Eastern Atlas and the location of the hand augerings (2013).

Consequently, geoelectrical resistivity surveys were conducted to understand the subsurface structures in depth, which is not possible with geomagnetic surveys (Vermeulen et al., 2013). A 
south-north oriented resistivity transect of $74.25 \mathrm{~m}$ long, crossing the $d m e m$ around $45 \mathrm{~m}$, was laid out (Figure 4, white line). The resulting 2D-profile reveals vertical and lateral variations, which are related to the impact of archaeological structures near the surface and to the difference in type of sediments (Figure 5). The relatively high resistivity values, higher than $20 \Omega \mathrm{m}$, correspond with Roman structures and are spread over a zone in the profile of 39 to $57 \mathrm{~m}$. Another high resistivity area is present around 59 to $60 \mathrm{~m}$. Underneath the topsoil, a highly conductive layer with a depth around $2 \mathrm{~m}$ could be identified, which indicate a clayey soil with highly conductive groundwater such as brackish water or salt water intrusions (Vermeulen et al., 2013). The third applied geophysical technique was the Ground Penetrating Radar (GPR) survey during the 2013 campaign. This method creates 3D images and served to obtain complementary information on the earlier detected magnetic anomalies (Vermeulen, De Dapper, et al., 2009). However, the results were limited since only the $d m e m$ could be detected at an estimated depth of $55-60 \mathrm{~cm}$. No archaeological monuments were visible on the 3D images, which may be due to the high clay content of the soil and/or the depth of the funerary structures (Vermeulen et al., 2013). Hand augerings showed an average depth of $1 \mathrm{~m}$ for most archaeological structures.

Figure 5 2D-profile of the resistivity transect crossing the Roman road (dmem), executed by Eastern Atlas (2013), and location of the hand augerings.

A total of 23 augerings in the western suburbium of Potentia were carried out in the 2012 and 2013 campaigns of the PVS-project. During 2013, a NNW-SSE transect of 13 augerings, perpendicular to the Roman $d m e m$, was set out to verify the Roman road and its subsurface structure, and to gather historical and archaeological landscape information. This transect largely coincides with the resistivity transect in order to combine the stratigraphy from the resistivity imaging with soil samples. The location of some of these hand augerings was also based on anomalies detected by the geophysical surveys. The presence of the Roman road was verified at a depth of 50 to $64 \mathrm{~cm}$ below the surface. Moreover, three positive magnetic anomalies were identified as archaeological structures (see numbered pink circles in Figure 4). In the first anomaly (Figure 4, HA 21) archaeological material is present from a depth of $205 \mathrm{~cm}$, in the second from $100 \mathrm{~cm}$ deep onwards (Figure 6, HA 3) and in the augerings performed on the location of the third magnetic anomaly, from 90 to $115 \mathrm{~cm}$. The archaeological layer consisted of brick fragments, mortar, sandstone, charcoal and ceramics. The ceramics in these layers were studied by P. Monsieur and could be attributed to the Roman period. It cannot, however, be stated with complete certainty that these subsurface structures are funerary monuments but based on the aerial photographs and the funerary relict in the landscape this may be reasonably assumed (Vermeulen et al., 2013). Based on these results, other slightly positive magnetic anomalies along the dmem are also interpreted as archaeological anomalies (see dark blue marks in Figure 4).

The second objective of hand augering was obtaining more insight in the construction of the road and of the raised platform on which it was likely built. The center of this platform lies near HA 1 and 5, where it has a maximum thickness of $100 \mathrm{~cm}$ (Figure 6). The platform had a width of at least $7 \mathrm{~m}$ and was constructed with flattened, elongated and rounded gravel, which indicates the 
use of beach ridge material. The augerings contained several fragments of ceramics; the ones from augering 21 (located at a magnetic anomaly) can be dated in the Late Republican and/or Early Imperial Age (ca. 180 BC - 40 AD), coinciding with the first two centuries of life at Potentia. Ceramics found at a depth of $310 \mathrm{~cm}$ in augering 22 are possibly Protohistoric, but a finer dating in the Bronze or Iron age cannot be obtained (Pincé, 2013).

The results of the resistivity survey can be compared with the hand augerings to explain the differences in conductivity visible on the 2D-profile. The highly resistant features between 43 to 52 are clearly related to the Roman road (dmem) and the relatively high resistivity spot around 60 $\mathrm{m}$, coinciding with augering 10, consists of an anthropogenic layer from 85 to $130 \mathrm{~cm}$ (Vermeulen et al., 2013). The anomaly from the magnetic survey that could be verified in augering 3 (Figure 6) is not visible in the resistivity model. The highly conductive layer at a depth from 1 to $3 \mathrm{~m}$ coincides with clayey silt sediments (Vermeulen et al., 2013).

Figure 6 Hand augering profiles showing the Roman road (dmem) in HA 5, 1 and 17, the archaeological features correlated with a magnetic anomaly in HA 3 and the beach ridge in HA 1.

\subsection{Coastal and Fluvial Changes in the Suburbium}

Coastal and fluvial alternations were predominant in this landscape during ancient times. These environmental changes had implications on the town since it influenced the location of the harbor, the extension of the city towards the east and the orientation and form of the Roman street grid. Moreover, it affects the usability of the applied techniques (Goethals et al., 2009). To elucidate the environmental situation in parts of the town's suburbium, the combination of aerial photography analysis, geomorphological fieldwork, geoelectrical resistivity surveys and hand augerings was suitable (Goethals et al., 2009; Vermeulen \& Verhoeven, 2006). Based on the integration of these techniques, the river diversions of the Potenza and the coastline progression since Roman times could be reconstructed.

During the Roman period, the Potenza channel was located directly south of the colonial town of Potentia, flowing in the middle of the valley and under the Casa dell' Arco bridge (Goethals et al., 2009; Vermeulen, 2003; Vermeulen, Monsieur, et al., 2005; Verreyke, 2007 p. 155-157) (Figure 2). Radiocarbon datings showed the Potenza followed this course until the $14^{\text {th }}$ century AD. However, the location of the estuary probably changed in the Early Middle Ages to the southeastern corner of Potentia, which possibly contributed to the final abandonment of the town area. It must also have erased the presumed structures of a small river mouth port located near the southern gate. From the $14^{\text {th }}$ to the $16^{\text {th }}$ century $\mathrm{AD}$, the Potenza changed its courses several times, as well by natural as by man-made causes, gradually filling the valley plain with a thick veneer of alluvial sediment. Even with a more stabilized river course at the northern edge of the plain since early modern times, regular floods continued to shape the more and more flattish valley bottom near the coast (Vermeulen, Monsieur, et al., 2005; Verreyke, 2007 p. 157). 


\section{INTRA-MURAL AUGERINGS AT TREA}

\subsection{The Site and its Investigation}

The site of the Roman urban settlement of Trea is situated on a plateau $1 \mathrm{~km}$ northwest of modern Treia, in the middle valley of the Potenza river. The plateau, situated $308 \mathrm{~m}$ a.s.1. and $70-80 \mathrm{~m}$ above the present-day valley bottom, is part of a Middle-Pleistocene alluvial terrace composed of a thick layer of gravel with alternating thin layers of silt and clay. The site offers several benefits: a wide view over the river plain, defence due to the elevation and the steep slopes partly bordering the rims and an excellent drainage thanks to the gravel content of its soil. Moreover, a nearby source located at the footslope of the uphills provides a permanent water supply. Due to the loose sedimentary characteristics of the superficial geological formations, the area is suitable for agriculture. As a consequence, however, the soil is also vulnerable for landslides and erosion (Costantini, Urbano, \& L'Abate, 2004). Except for the monastery of SS. Crocifisso and a couple of rural houses, the plateau is nowadays fully used for agriculture. From the $16^{\text {th }}$ century onwards, Trea was studied by various interested parties. In 1812, F. Benigni published a report on his 'excavations', which meant a first breakthrough in the investigations of the city (Moscatelli, 1988). In the 1970s the University of Marcerata based their research on vertical aerial photography and topographical studies and in the 1980s the same university excavated some parts of the plateau under supervision of G. M. Fabrini. These studies made it possible to obtain a preliminary understanding of the town (Marengo, 2000; Vermeulen, Slapšak, et al., 2012). It was only in 2003 that the town could be mapped in detail, thanks to the exceptionally clear crop marks on the oblique aerial images taken during the PVSproject (Vermeulen \& Verhoeven, 2006). In 2007, geophysical prospections, based on the previous results and the new aerial photographs, were carried out in the frame of the PVS-project especially focusing on the central town area (Vermeulen, De Dapper, et al., 2009). The geoelectrical resistivity method revealed many buried stone structures and other human made anomalies. By using the magnetic method with an induced type of magnetization, an even wider range of remains was detected such as structures of brick and tile, kilns and hearths. The combined results of these measurements made it possible to enhance the archaeological interpretation and to distinguish stone built structures from brick ones. In addition, an extensive Ground Penetrating Radar (GPR) survey was tried in 2013, but the terrain conditions at Trea were not favourable; because of the high percentage of clay in the soil the results of the GPR survey were blurred. Next to these remote sensing techniques and geophysical measurements, intensive artifact surveys were carried out during several field campaigns to further improve qualitative and chronological detail (Vermeulen, De Dapper, et al., 2009). Everything included, these now established approaches of urban survey created an excellent documentation of a small Roman town, which was fully provided with an impressive forum and series of public buildings, a basic street grid, a full defence system with gates and towers, areas of intra-mural housing and commercial zones since its municipalisation of around 50 BC (Figure 7). Most of these urban structures could now be mapped, and even some data on transformations of the urban space through time were obtained without excavation. 
Figure 7 Interpretation of city layout based on remote sensing analyses and geophysical prospections. The dotted lines are less certain interpretations.

To verify these non-invasive techniques even further, a geoarchaeological augering survey was done during the PVS-campaign of 2013 based on the results of previous investigations. This survey provides a better context for the suggested archaeological interpretations of the previous work. In addition, information was obtained about the state of conservation of the archaeological materials and an insight into the on-site geomorphology of the Roman town was acquired.

\subsection{Results of the Augering Campaign}

The intra-mural area of the site was divided into six zones of interest and 54 hand augerings were conducted (Figure 8). In what follows, the relationship between the different prospection results and the most remarkable results will be described (Weekers, 2015). This comprises first the specific archaeological results and second a series of results regarding the geomorphology of the site.

Figure 8 Orthophoto based on oblique low altitude photography over the abandoned town site of Trea, showing a multitude of crop marks that reveal urban structures. The locations of the hand augerings are indicated.

The monumental center of the site was investigated by a transect of 18 augerings (Figure 8, zone 1). On the aerial photographs and geoelectrical data, the forum square is clearly distinguishable but the augerings could not prove the existence of any remnants of a large pavement. The percentage archaeological material in these samples was not exceptional and the preservation depth underneath the square is approximately $1 \mathrm{~m}$, which is not remarkably deeper than in any other area of the site. Most probably the paving of the square has disappeared as the result of spoliation after the abandonment of the town, but we cannot exclude that the plaza never received a stone paving, as was not unusual in smaller towns. The crop marks south of the forum square are less clear in comparison to the ones at the northern border. Despite this, the augerings attested a thick layer of preserved material with an outstanding number of mosaics. The zone north of the forum seems to be build in more massive/permanent building materials such as limestone, sandstone and gravel. This can explain the better visibility of the cropmarks north of the square. Noteworthy are the two structures in the northwestern corner of the forum, because they are not visible on the geomagnetic data (Figure 9b). The augering survey could confirm these structures must mainly consist of gravelbased foundations, which would explain their absence on the magnetic image.

Figure 9 Detailed mapping of (a) aerial photography, (b) geomagnetic and (c) geoelectrical resistivity data with hand augering locations in the northwestern part of the forum area. (d) Augering profiles with gravel based foundations.

The study of the archaeological material recovered from these soil samples dates predominantly in the $1^{\text {st }}$ and $2^{\text {th }}$ century AD. However, in the zone south of the square twelve coins were found $60 \mathrm{~cm}$ beneath the surface, which can be dated in the Late Antique period $\left(4^{\text {th }}-5^{\text {th }}\right.$ century AD). Another remarkable fact is that in the zone south of the forum and underneath the basilica Republican material was discovered in some augerings at a depth of approximately $1 \mathrm{~m}$. The existence of differently orientated structures in this area, visible on the aerial images (Figure 8, hatched zone), could also be related to this (possibly older) material. These Republican fragments might indicate an 
older occupation layer, and therefore an earlier phase of urbanization in this part of the settlement. The results of the on-going C-14 analyses of the charcoal fragments could shed some more light on this important chronological issue.

Until now, there is no proof of the existence of preserved prehistoric occupation layers at Trea. This does not exclude the presence of prehistoric occupation, as suggested by the new finds, but further research is necessary. A Republican building phase prior to the construction of the mainly Early Imperial monuments must be confirmed, corroborating the hypothesis of an older habitation layer predating the monumental forum phase.

In the zone west of the forum complex (Figure 8, zone 3) seven augerings were executed, which all attest that the archaeological layer in this area is quite well preserved. For instance, the presence of the basilica on the western short side of the forum square is not only clearly visible on the aerial images and in geoelectric and magnetic data, but this suggested preservation quality can now also be confirmed(Vermeulen, Monsieur, et al., 2005) through the augering survey. In addition, the area east of the monumental center is quite well known thanks to the prospection images and is interpreted as a zone dominated by wealthy houses of the domus-type. The four augerings conducted in this area confirm the quite good conservation of the remains and prove the impenetrable characteristics of the soil due to the presence of archaeological material.

In the northwestern corner of the town (Figure 8, zone 4), the magnetic survey results show a few very visible anomalies (Figure 10b). In the sample of the augering (HA 49), metal slag and some overfired tiles were recognised, which might relate to the existence of kilns or other strongly burnt materials in this zone. The northern edge of the plateau is bordered by an elongated irregular cropmark visible on the aerial photographs (Figure 8). The geophysical prospection did not extend until this edge so further examination of this anomaly was done by augering at two different locations (Figure 8, zone 2 and 4). The sediment profiles did prove this cropmark to be strictly natural and it can now be seen as part of the Pleistocene river terrace. No traces of levelling or modelling of the plateau by the Romans could be recognised in these soil profiles, which of course does not exclude a landscape modification elsewhere in the town.

Figure 10 Detailed mapping of (a) aerial photography, (b) geomagnetic and (c) geoelectrical resistivity data with hand augering locations in the northwestern part of the intra-mural town area.

Next to the study of the archaeological traces and material, the augerings could also provide insight in the (geomorphological) degradation of the site. The edges of the site seem to be quite vulnerable to erosion. In the north (Figure 8, zone 2) a steep slope of $10 \%$ was attested, which can indicate slope erosion. It can be noted that the concentration of archaeological material ${ }^{1}$ at the edges of the town only amounts $0.5 \%$, where in the center of the site an average of $5 \%$ was attested.

At the northwestern border of the site (zone 4), the effect of slope erosion is less distinct, the slope gradient is only $2 \%$, but the percentage of archaeological material is also quite low. Augering 48

\footnotetext{
${ }^{1}$ These percentages are measured by weighing the archaeological material in each sample.
} 
(Figure 10) can be seen as an exception: in this sample much material was found (at least until a depth of $190 \mathrm{~cm}$ ) dating from the Bronze / Iron Age (2200-300 BC) to the Late Antique / Early Middle Ages. It is very probable that this context must be interpreted as a waste deposit, instead of a colluvial layer.

The northeastern corner of the site (Figure 8, zone 6) is clearly disturbed. The aerial photographs are empty of cropmarks (Figure 11a) and the traces on the geophysical images are very disordered (Figure $11 \mathrm{~b}$ and $4 \mathrm{c}$ ). A transect of augerings was carried out to investigate this difficult interpretable area (Figure 12). The study of the soil profiles points to the presence of a landslide. In this zone the plough layer is succeeded by a very clayey impervious layer (HA 38, 39, 36 and 34), which prevents water infiltration and quickly ensues top soil saturation after heavy or prolonged rainfall. In case of steep slopes (here $11 \%$ ) the right conditions for landsliding, a quite common geomorphological process in this hilly region of Italy, are present (Costantini et al., 2004). The soil profile clearly shows the occurrence of erosion and the accumulation of archaeological material downhill. Augering 37 shows an exceptionally thick layer $(2.1 \mathrm{~m})$ with archaeological material, the low percentage $(1 \%)$ and the mixed nature of the material confirmed the colluvial characteristics. It is likely that in this sector erosion took place on a higher level.

Figure 11 Detailed mapping of (a) aerial photography, (b) geomagnetic and (c) geoelectrical resistivity data with hand augering locations in the northeastern part of the intra-mural town area.

Figure 12 Hand augering profile showing possible landslide

\section{CONCLUSION}

It is particularly clear from recent research in many parts of the Roman Mediterranean world that non-invasive survey is crucial in the process of revealing and studying ancient urban contexts. Especially when this type of archaeological detection can be continued over a span of several years, making good use of the diversity of seasons and methods. The case studies presented here show very distinctly the need for geoarchaeological approaches if we want to deal with the sometimes very high stratigraphic complexity of the surveyed urban sites and the very dynamic landscapes they are part of. In-site geoarchaeological analysis first and foremost focuses on the genesis of the archaeological sites, which are the formation processes on the scale of the sites themselves and on the factors leading to the fossilization, preservation or reworking of the archaeological remains (Rapp \& Hill, 1998). It is thus complementary with the purely archaeological, traditional stratigraphic approach. It allows to establish the origin of the archaeological sediment and their evolution by highlighting what is linked with the anthropogenic, cultural and bio-pedological processes as well as the geological depositional (sedimentary) and/or post-depositional factors, which are so important in abandoned Roman towns sites.

Both presented case studies illustrate very well the need for complementing now already established ways of non-invasive archaeological survey with a more in-depth geoarchaeological 
strategy. The remote sensing and geophysical techniques were very useful to uncover new data about subsurface archaeological features in and around the city of Potentia and about coastal and fluvial changes. However, the implementation of hand augerings appeared to be vital for the study of depositional environments such as those of the lower Potenza valley and for the verification of geophysical and remote sensing results. Moreover, this method allowed an insight in the dynamic processes of the urban landscape through time. The spatial resolution of these augerings was in function of the research questions and the results of other non-invasive techniques. More augerings could have been useful to verify other magnetic anomalies. However, the augerings were strategically chosen in order to achieve a thoughtful interpretation of these anomalies. The geoarchaeological techniques are combined with artifact studies, grid field walking, study of historical sources and excavations to elucidate the settlement history of Potentia and its relationship with the surrounding landscape. It must be stressed that the implementation of these geoarchaeological survey methods was mainly possible here thanks to the largely agricultural function of the area today. However, the increasing coastal tourism in and around Porto Recanati exerts huge pressure on the area of the former Roman town and its suburbium. To meet the needs of the tourists, a new commercial complex was recently planned in the southern suburbium, which would partly destroy the Roman estuary of the Potenza, the possible harbor and many other buried, archaeological structures and traces. However, our archaeological research prevented these destructive interventions, making way for a wider protection of the ancient site and its buffering landscape. The use of non-destructive, interdisciplinary techniques for the study of the former urban area is thus important for heritage management since, based on their results, guidelines for urban planning can now be established here.

The case study of the abandoned urban site of Trea shows well that intensive and focused augering survey is a useful tool in a detailed non-invasive study of former intra-mural areas and their landscape transformations. Firstly, the depth of the preserved archaeological strata and structures can be quite accurately estimated, without costly excavation work. In Trea, the archaeological layer has a thickness of approximately $1 \mathrm{~m}$, with the exception of some particular zones where the material only reaches a depth of $30 \mathrm{~cm}$. These results demonstrate the importance of the technique for focused archaeological heritage management. The amplification of modern agriculture at Trea and the unawareness of the wider public about this 'hidden' archaeological patrimony are a direct threat to the archaeological record. Modern agricultural activities can harm the archaeological record and may lead to the fading or disappearance of the temporarily visible cropmarks and the archaeological layer. The intensification of agriculture will also cause an increase of tillage erosion, especially at the steepest borders of the plateau. To recommend the required measures for heritage management, augerings are an efficient tool. Furthermore, it is clear that the material in the augering sequences allows better insight in previous occupation layers than offered by simple surface control. The augering survey allowed also to verify the nature of many cropmarks and to explain the characteristics of certain anomalies. In addition, the relation between different prospection images could now be clarified 
based on the material in the soil samples. The study of post-depositional processes provides an important insight in the degradation and preservation of a site. It can be noted that erosion processes caused an accumulation of colluvium downhill; the steeper the slope the more material is accumulated. Furthermore, the augerings in the northeast sector of the site point to a landslide, to be confirmed by further research. Based on these results, it can be stated that the chosen frequency of the augerings on the site was appropriate.

Both study cases demonstrated that the integrated mapping of buried urban structures also needs to be undertaken at different levels, i.e. at different scales, ranges of precision and with variety in the depiction of interpreted detail. Only with a better comprehension of the current and the buried geomorphology of the site can non-invasive survey evidence, such as from aerial archaeology or geophysical prospection data, reveal their full potential for the archaeology of former (and current) urban contexts. Today, still only very few non-invasive survey projects based on aerial photography and systematic geophysical prospections involve regular observation of soil profiles as a means of direct calibration and control (Jordan, 2013). Also the objective evaluation of soil moisture is rarely undertaken at such instances while, especially for aerial photography results but also for certain geophysical methods (e.g. GPR and earth resistance survey), this kind of information is crucial. As it is now clear that no prospection method detects all archaeological remains under all circumstances, we need to understand more fully the structure and behavior of remains and their environments. Together with a better assessment of the depth, nature and preservation of the archaeological structures, the combination of an air photograph or geophysical prospection image with the more systematic use of the auger-hole (and possibly the soil test-pit), holds the promise for substantial advances in geoarchaeological understanding of urban archaeological landscape

\section{Acknowledgements}

The Potenza Valley Survey project (http://www.flwi.ugent.be/potenza), directed by F. Vermeulen and operated by a team from Ghent University, is financed by the Belgian Science Policy (IAP program) and the Fund for Scientific Research - Flanders and Ghent University. Geoarchaeolocial operations are co-directed by M. De Dapper. Additional contributions for the study and mapping of the town centers come from teams of the Universities of Ljubljana and Southampton, the British School at Rome and Eastern Atlas. For a recent overview of these urban surveys with ample bibliography see Vermeulen, 2012b. The authors are grateful for the constructive comments on this paper provided by the reviewers. 


\section{REFERENCES}

Barber, M. (2011). A history of aerial photography and archaeology. Mata Hari's glass eye and other stories. Swindon: English Heritage.

Berendsen, H.J.A. (2005). Fysisch-geografisch onderzoek: thema's en methoden. Assen: Koninklijke van Gorcum.

Bintliff, J., \& Snodgrass, A. (1985). The Cambridge/Bradford Boeotian expedition: the first four years. Journal of Field Archaeology, 12, 123-161.

Bintliff, J., \& Snodgrass, A. (1988). Mediterranean survey and the city. Antiquity, 62, 57-71.

Bourgeois, J., \& Meganck, M. (2005). In Aerial Photography and Archaeology 2003. A Century of Information. Paper presented at the Congress Aerial photography and archaeology: a century of information (2003), Ghent. Academia Press.

Christie, N. (2012). Urban landscape surveys: a view from the end. In F. Vermeulen, G.-J. Burgers, S. Keay \& C. Corsi (Eds.), Urban landscape Survey in Italy and the Mediterranean (pp. 285-289). Oxford: Oxbow.

Coltorti, M. (1989). Il quaternario continentale e l'evoluzione del paesaggio della regione Marchigiani. In N. N. (Ed.), La preistoria e studi preliminari di preistoria nella provincia di Ascoli Piceno - Atti del corso di aggiornamento per persoale direttivo e docente della scuola - Cupra Marittima (pp. 321-359).

Coltorti, M. (1991). Modificazioni morfologiche oloceniche nelle piane alluvionali marchigiane: Alcuni esempi nei fiumi Misa, Cesano e Musone. Geografica Fisica e Dinamica Quaternaria, 14(1), 73-86.

Coltorti, M. (1997). Human impact in the Holocene fluvial and coastal evolution of the Marche region, Central Italy. Catena, 30, 311-335.

Corsi, C., Slapšak, B., \& Vermeulen, F. (2013). Good practice in archaeological diagnostics. Non-invasive survey of complex archaeological sites (Vol. 69). Cham: Springer.

Costantini, E., Urbano, F., \& L'Abate, G. (2004). Soil regions of Italy. CRA-ISSDS, Firenze.

Doneus, M. (2004). Aerial archaeology in the landscape of Carnuntum. Archaeologia Aerea. Studi di Aerotopografia Archaeologica, I, 215-234.

Goethals, T., De Dapper, M., \& Vermeulen, F. (2005). Geomorphology and geoarchaeology of three sites in the Potenza Valley Survey (The Marches, Italy): Potentia, Montarice and Helvia Recina. Revista de geomorfologie, 7, 33-49.

Goethals, T., De Dapper, M., \& Vermeulen, F. (2009). Geo-archaeological implications of river and coastal dynamics at the Potenza river mouth (The Marches, Italy). In M. De Dapper, F. Vermeulen, S. Deprez \& D. Taelman (Eds.), Ol'Man River. Geo-archaeological aspects of rivers and river plains (pp. 415-448). Ghent: Academia Scientific.

Guaitoli, M. (2003). Lo sguaro di Icaro. Le collezioni dell'Aerofototeca Nazionale per la conoscenza del territorio. Roma: Campisano.

Johnson, P.S., \& Millett, M. (2012). Archaeological Survey and the City (Vol. 2). Oxford: Oxbow.

Jordan, D. (2013). A geoarchaeologists view of aerial archaeology. AARGnews, 29-36.

Marengo, S.M. (2000). Regio V: Picenum. Supplementa italica. Nuova serie, 18, 155-188.

Martinez del Pozo, J.A., \& Mayoral Herrera, V. (2013). Creating and analysing digital terrain models for archaeological research. In C. Corsi, B. Slapšak \& F. Vermeulen (Eds.), Good practice in archaeological diagnostics. Non-invasive survey of complex archaeological sites. New York: Springer.

Moscatelli, U. (1988). Trea, (Forma Italiae). Firenze: Leo S. Olschki Editore.

Neubauer, W., \& Eder-Hinterleitner, A. (1997). Resistivity and magnetics of the Roman town Carnuntum, Austria: an example of combined interpretation of prospection data. Archaeological Prospection, 4, 179-189.

Neubauer, W., Eder-Hinterleitner, A., \& Melichar, P. (2002). Georadar in the Roman civil town Carnuntum, Austria: an approach for archaoelogical interpretation of GPR data. Archaeological Prospection, 9(3), 135-156.

Pincé, P. (2013). Landschappelijke inplanting van Romeinse villa's in het mondingsgebied van de Potenza (De Marken, Italië). Unpublished Dissertation: Ghent University - Department of Geography.

Rapp, G., \& Hill, C. (1998). Geoarchaeology: the earth science approach to archaeological interpretation. New Haven: Yale University Press.

Scollar, I., Tabbagh, A., Hesse, A., \& Herzog, I. (1990). Archaeological Prospecting and Remote Sensing. Cambridge: Cambridge University Press.

Verhoeven, G. (2008). Imaging the invisible using modified digital still cameras for straightforward and low-cost archaeological near-infrared photography. Journal of Archaeological Science, 35(12), 3087-3100.

Verhoeven, G. (2012). Near-Infrared aerial crop mark archaeology: from its historical use to current digital implementations. Journal of Archaeological Method Theory, 19, 132-160.

Verhoeven, G., Doneus, M., Briese, C., \& Vermeulen, F. (2012). Mapping by matching - A computer vision-based approach to fast and accurate georeferencing of archaeological aerial photographs. Journal of Archaeological Science, 39(7), 20602070.

Verhoeven, G., Loenders, J., Vermeulen, F., \& Docter, R. (2009). Helikite aerial photography - a versatile means of unmanned, radio controlled, low-altitude aerial archaeology. Archaeological Prospection, 16, 125-138.

Verhoeven, G., \& Schmitt, K.D. (2010). An attempt to push back frontiers - digital near-ultraviolet aerial archaeology. Journal of Archaeological Science, 37(4), 833-845.

Verhoeven, G., Smet, P., Poelman, D., \& Vermeulen, F. (2009). Spectral characterization of a digital still camera's NIR modification to enhance archaeological observation. IEEE Transactions in Geoscience Remote Sensing, 47, 3456-3468.

Vermeulen, F. (2003). The Potenza Valley Survey: preliminary report on field campaign 2002. BABESCH, 78, 71-106. 
Vermeulen, F. (2004). Fotografia aerea finalizzata nelle Marche Centrali: Un progetto integrato. Archeologia Aerea Studi di Aerotografia Archeologica, 1, 91-118.

Vermeulen, F. (2012). Potentia: a Lost New Town. In N. Christie \& A. Augenti (Eds.), Urbes Extinctae. Archaeologies of Abandoned Classical Towns (pp. 77-95). Farnham: Ashgate.

Vermeulen, F. (2013a). Interdisciplinary non-invasive survey approaches to ancient towns: some applications and visualisations from the Roman West. In J. Poblome (Ed.), Exempli Gratia: Sagalassos, Marc Waelkens and Interdisciplinary Archaeology (pp. 165-182). Leuven: Leuven University Press.

Vermeulen, F. (2013b). Roman Urban Survey: the mapping and monitoring of complex settlement sites with active aerial photography. In C. Corsi, B. Slapšak \& F. Vermeulen (Eds.), Good practice in archaeological diagnostics. Non-invasive survey of complex archaeological sites (69 ed., pp. 69-85). Cham: Springer.

Vermeulen, F., Burgers, G.-J., Keay, S., \& Corsi, C. (2012). Urban Landscape Survey in Italy and the Mediterranean. Oxford: Oxbow.

Vermeulen, F., \& De Dapper, M. (2000). In Geo-archaeology of the Landscapes of Classical Antiquity (Vol. 5, pp. VI-233). Paper presented at the International Colloquium Ghent (1998), Leuven. Peeters.

Vermeulen, F., De Dapper, M., Monsieur, P., De Paepe, P., Verdonck, L., Taelman, D., et al. (2012). Archaeological Investigations in the Potenza Valley - Field Season 2012. Unpublished Report: Ghent University - Department of Archaeology.

Vermeulen, F., De Dapper, M., Monsieur, P., Verhoeven, G., Verdonck, L., Taelman, D., et al. (2013). Archaeological Investigations in the Potenza Valley - Field Season 2013.

Vermeulen, F., De Dapper, M., Mušič, B., Monsieur, P., Verreyke, H., Carboni, F., et al. (2009). Investigating the impact of Roman urbanisation on the landscape of the Potenza Valley: A Report on Fieldwork in 2007. BABESCH, 84, 85-110.

Vermeulen, F., Monsieur, P., Boullart, C., Verreyke, H., Verhoeven, G., De Dapper, M., et al. (2005). The Potenza Valley Survey: Preliminary Report on Field Campaign 2003. BABESCH, 80, 33-64.

Vermeulen, F., Monsieur, P., Slapšak, B., Destro, M., Mlekuž, D., Verhoeven, G., et al. (2011). Archaeological Investigations in the Potenza Valley - Field Season 2010. Unpublished Report: Ghent University - Department of Archaeology.

Vermeulen, F., Monsieur, P., Slapšak, B., Groszman, D., Destro, M., Mlekuž, D., et al. (2009). Archaeological Investigations in the Potenza Valley - Field Season 2009. Unpublished Report: Ghent University - Department of Archaeology.

Vermeulen, F., Slapšak, B., \& Mlekuž, D. (2012). Surveying the Townscape of Roman Trea (Picenum). In P.S. Johnson \& M. Millett (Eds.), Archaeological Survey and the City (pp. 261-282). Oxford: Oxbow.

Vermeulen, F., \& Verhoeven, G. (2004). The contribution of aerial photography and field survey to the study of urbanization in the Potenza valley (Picenum). Journal of Roman Archaeology, 17, 57-82.

Vermeulen, F., \& Verhoeven, G. (2006). An Integrated Survey of Roman Urbanization at Potentia, Central Italy. Journal of Field Archaeology, 31, 395-410.

Vermeulen, F., Verhoeven, G., \& Semey, J. (2005). In J. Bourgeois \& M. Meganck (Eds.), The integration of Aerial Photography and GIS in the Potenza Valley Survey (4 ed., pp. 371-382). Paper presented at the Aerial Photography and Archaeology 2003 - A Century of Information, Ghent. Academia Press.

Verreyke, H. (2007). Late Roman pottery in the Potenza Valley. A framework for the study of towns, rural settlements and exchange in central Adriatic Italy. Ghent University, Ghent.

Weekers, L. (2015). De implementatie van grondboringen binnen de geo-archeologie, een case-study van het Romeinse Trea (Marche, Italië). Unpublished dissertation. Ghent University - Department of Geography. 


\section{FIGURES}

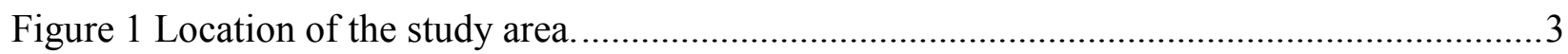

Figure 2 A reconstruction of the city layout of Potentia based on remote sensing analysis and

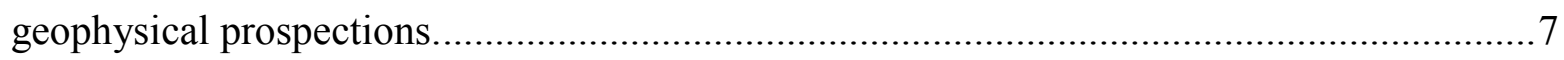

Figure 3 Digital Elevation Model (DEM) of Potentia based on micro-topographical measurements from the PVS-campaigns (a) and the DEM of LiDAR data from the Italian Ministery of Environment, created in 2009 (b).

Figure 4 Results and interpretation of the geomagnetic surveys (2012-2013) by Eastern Atlas and the location of the hand augerings (2013).....

Figure 5 2D-profile of the resistivity transect crossing the Roman road (dmem), executed by Eastern Atlas (2013), and location of the hand augerings.

Figure 6 Hand augering profiles showing the Roman road (dmem) in HA 5, 1 and 17, the archaeological features correlated with a magnetic anomaly in HA 3 and the beach ridge in HA 1.

Figure 7 Interpretation of city layout based on remote sensing analyses and geophysical prospections. The dotted lines are less certain interpretations.

Figure 8 Orthophoto based on oblique low altitude photography over the abandoned town site of Trea, showing a multitude of crop marks that reveal urban structures. The locations of the hand augerings are indicated.

Figure 9 Detailed mapping of (a) aerial photography, (b) geomagnetic and (c) geoelectrical resistivity data with hand augering locations in the northwestern part of the forum area. (d) Augering profiles with gravel based foundations.....

Figure 10 Detailed mapping of (a) aerial photography, (b) geomagnetic and (c) geoelectrical resistivity data with hand augering locations in the northwestern part of the intra-mural town area.

Figure 11 Detailed mapping of (a) aerial photography, (b) geomagnetic and (c) geoelectrical resistivity data with hand augering locations in the northeastern part of the intra-mural town area.

Figure 12 Hand augering profile showing possible landslide 


1
2
3
4
5
6
7
8
9
10
11
12
13
14
15
16
17
18
19
20
21
22
23
24
25
26
27
28
29
30
31
32
33
34
35
36
37
38
39
40
41
42
43
44
45
46
47
48
49
50
51
52
53
54
55
56
57
59
60

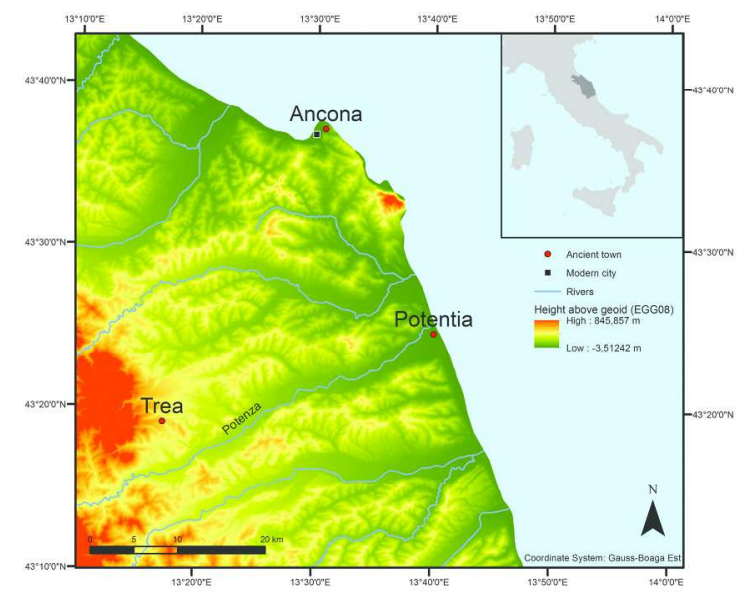

Location of the study area
$209 \times 148 m$ m ( $300 \times 300$ DPI)

John Wiley \& Sons 


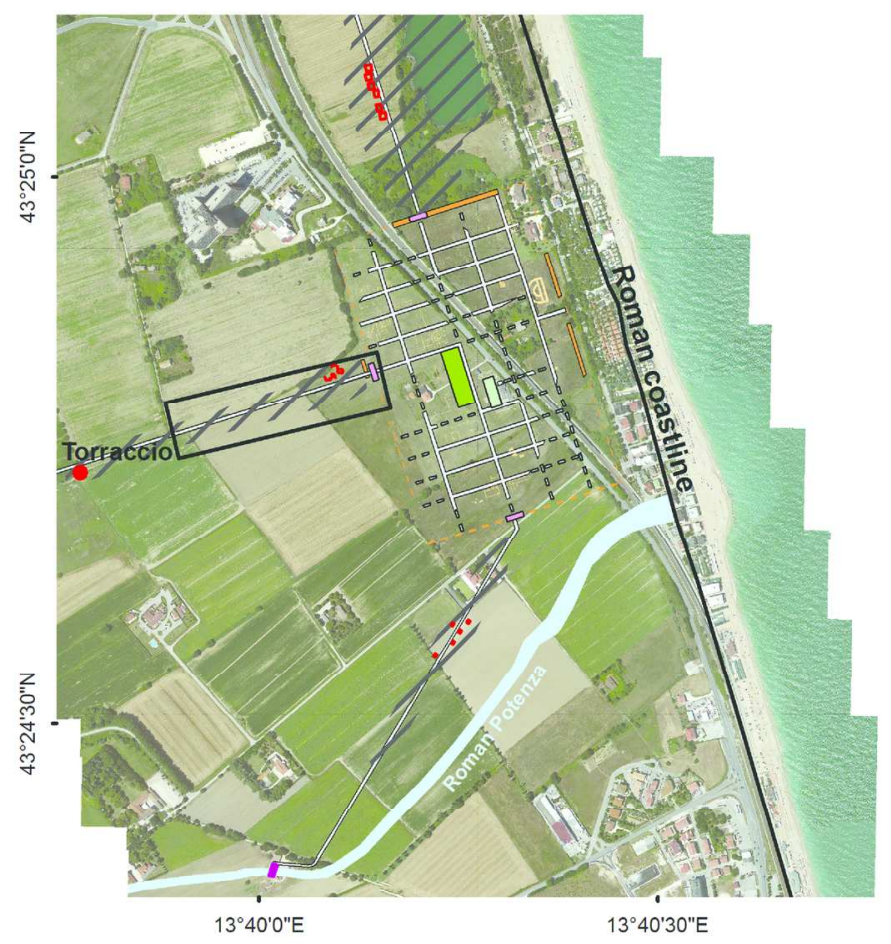

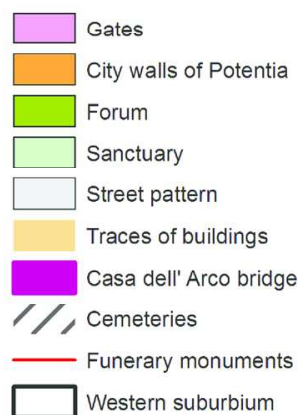

Coordinate system: Gauss Boaga Fuso Est Projection: Transverse Mercator Datum: Monte Mario

Background: Bing Maps 2013

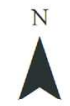

$0 \quad 125 \quad 250$

A reconstruction of the city layout of Potentia based on remote sensing analysis and geophysical prospections.

$80 \times 58 \mathrm{~mm}(600 \times 600 \mathrm{DPI})$ 

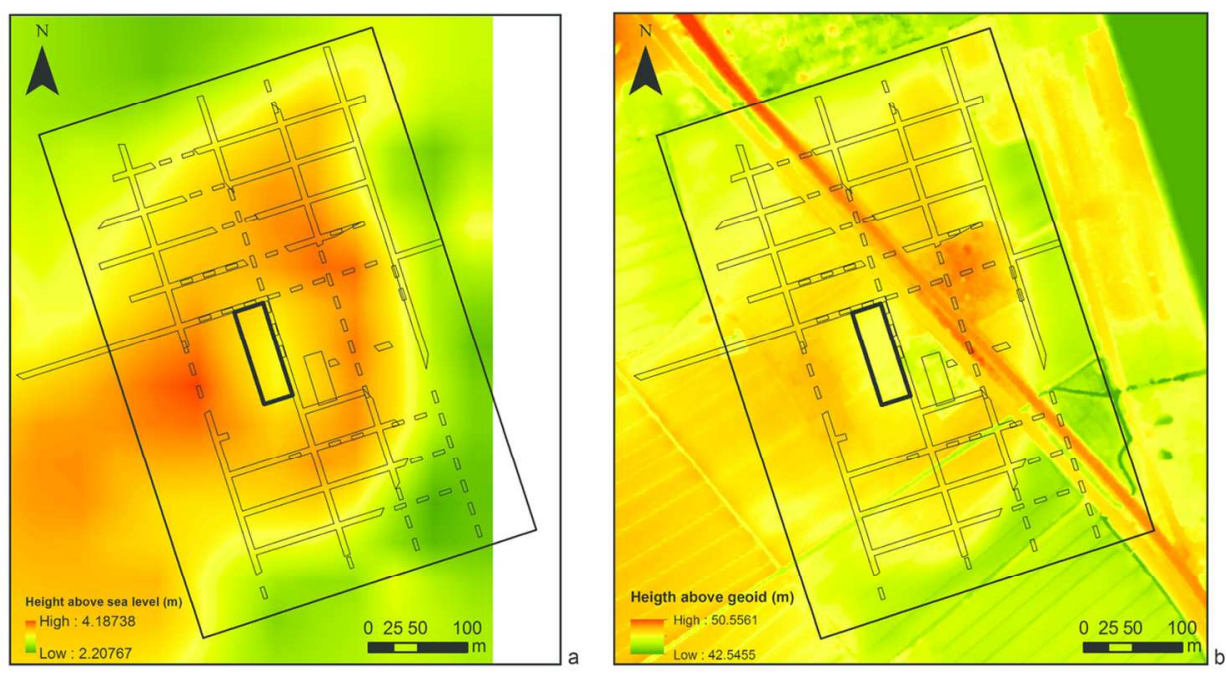

Digital Elevation Model (DEM) of Potentia based on micro-topographical measurements from the PVScampaigns (a) and the DEM of LiDAR data from the Italian Ministery of Environment, created in 2009 (b) $120 \times 65 \mathrm{~mm}(300 \times 300 \mathrm{DPI})$ 
Results and interpretation of the geomagnetic surveys (2012-2013) by Eastern Atlas and the location of the hand augerings (2013) $129 \times 80 \mathrm{~mm}$ (300 x $300 \mathrm{DPI})$ 


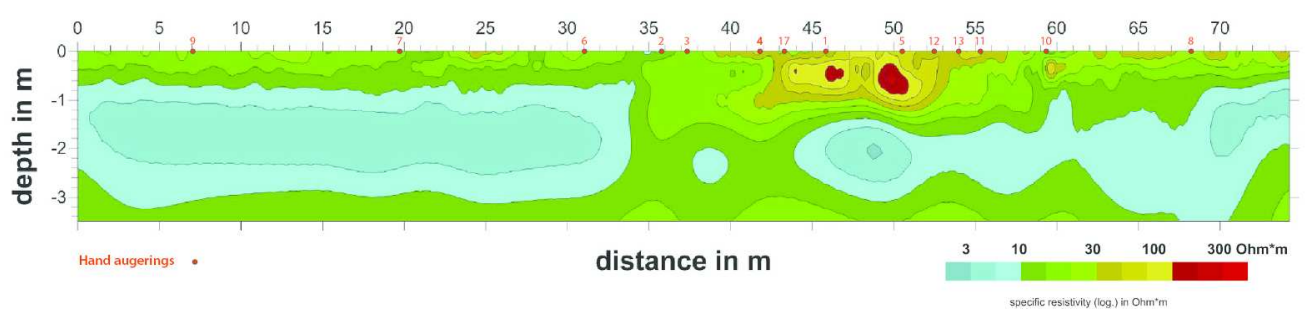

2D-profile of the resistivity transect crossing the Roman road (dmem), executed by Eastern Atlas (2013), and location of the hand augerings. $197 \times 44 \mathrm{~mm}(300 \times 300 \mathrm{DPI})$ 


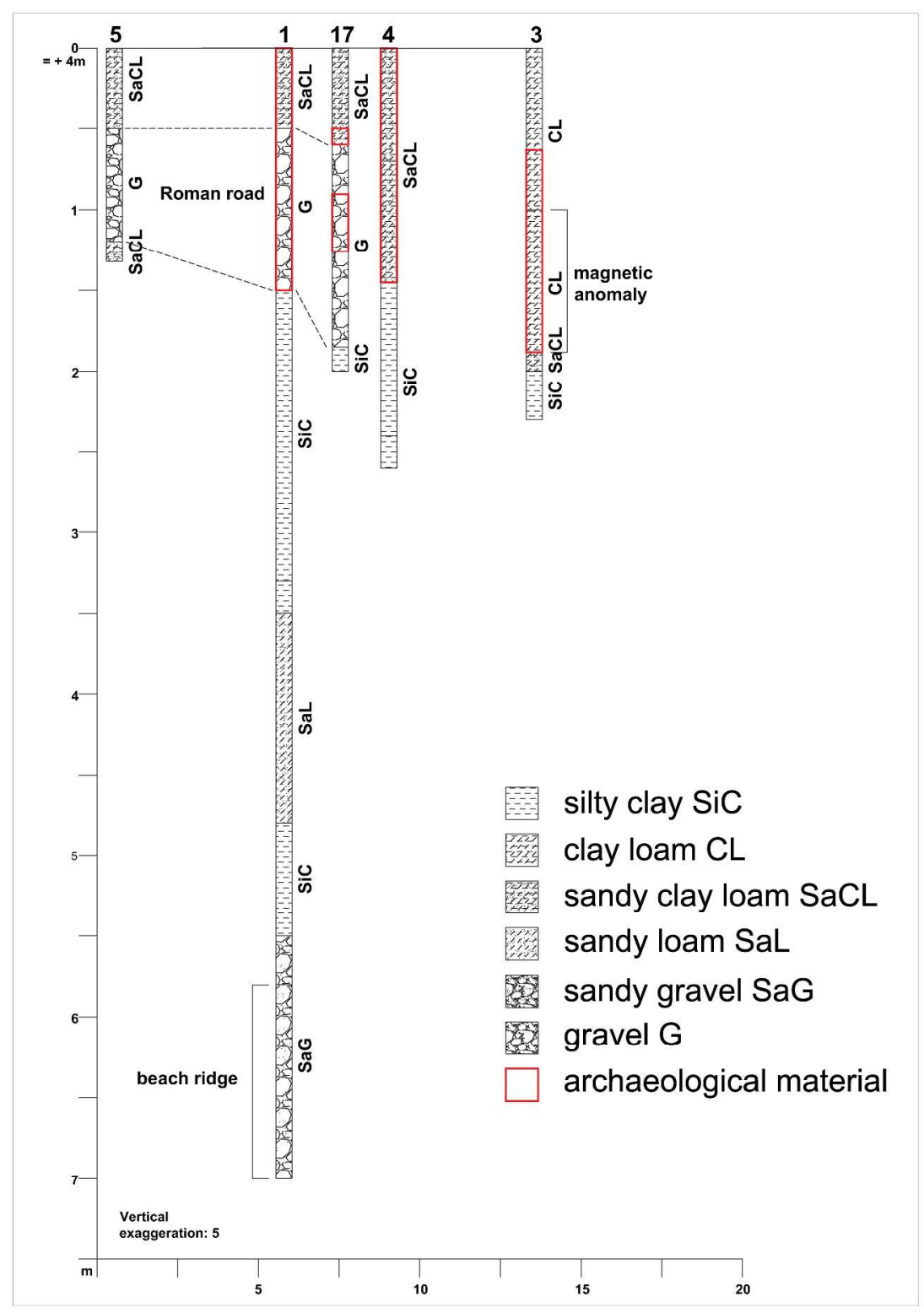

Hand augering profiles showing the Roman road (dmem) in HA 5, 1 and 17, the archaeological features correlated with a magnetic anomaly in HA 3 and the beach ridge in HA 1 $295 \times 418 \mathrm{~mm}(300 \times 300 \mathrm{DPI})$ 


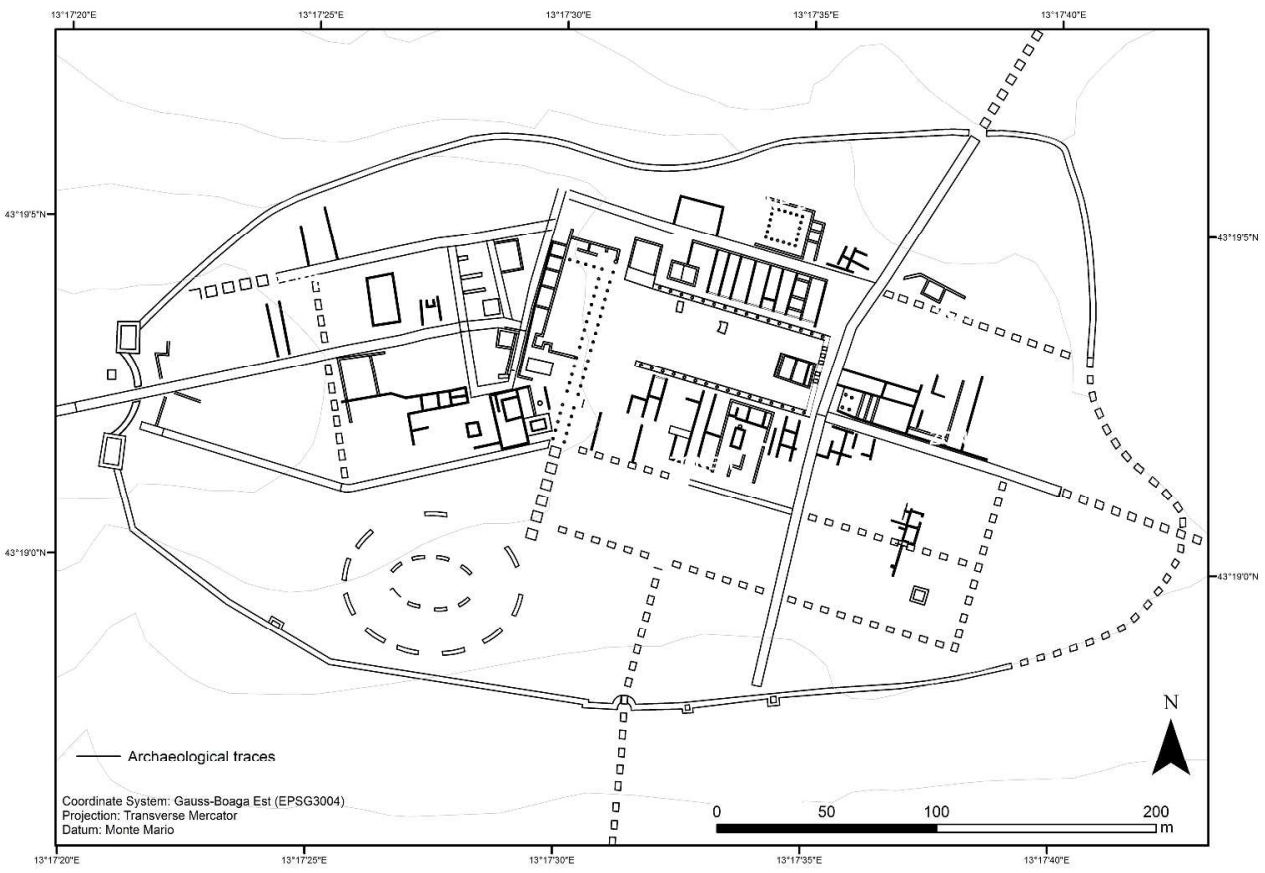

Interpretation of city layout based on remote sensing analyses and geophysical prospections. $593 \times 419 \mathrm{~mm}(300 \times 300$ DPI $)$ 


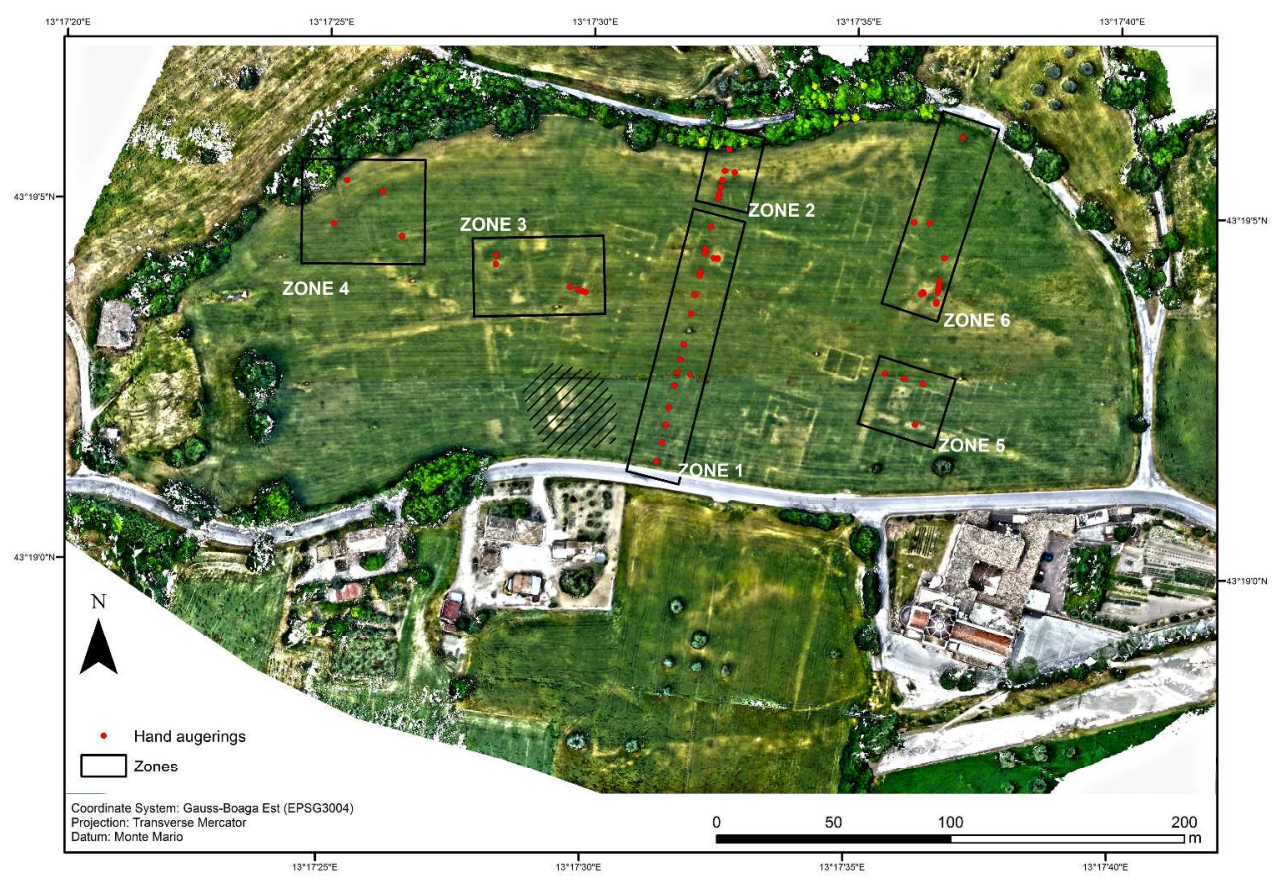

Orthophoto based on oblique low altitude photography over the abandoned town site of Trea, showing a multitude of crop marks that reveal urban structures. The locations of the hand augerings are indicated. $593 \times 419 \mathrm{~mm}(300 \times 300 \mathrm{DPI})$ 


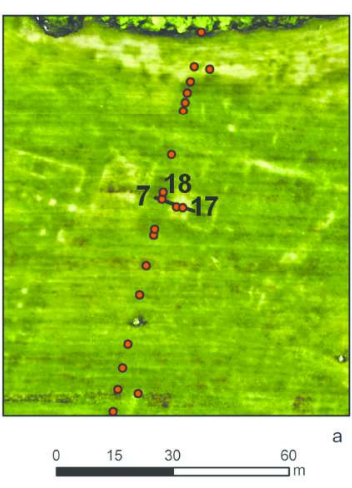

Coordinate System: Gauss-Boaga Est (EPSG3004) Projection: Transverse Mercator
Datum: Monte Mario

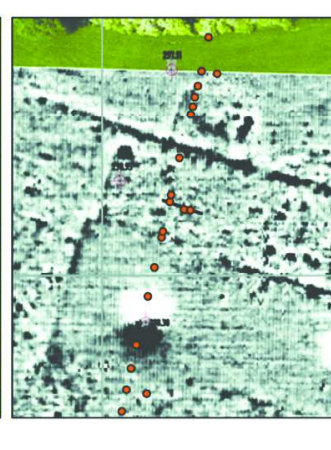

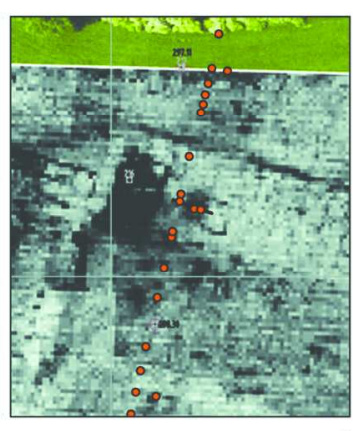

- Hand augerings Augering profile

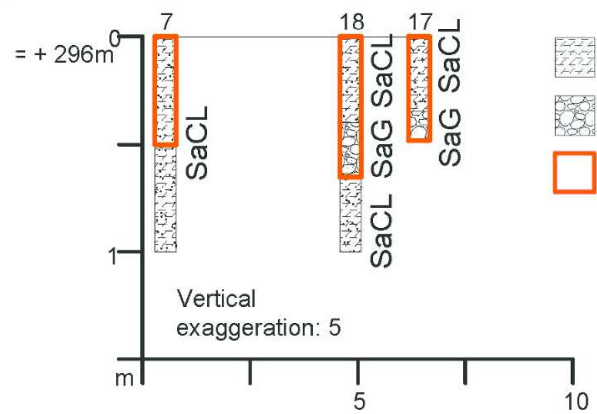

sandy clay loam SaCL sandy gravel SaG archaeological material

Detailed mapping of (a) aerial photography, (b) geomagnetic and (c) geoelectrical resistivity data with hand augering locations in the northwestern part of the forum area. (d) Augering profiles with gravel based foundations

$297 \times 420 \mathrm{~mm}(300 \times 300$ DPI $)$ 

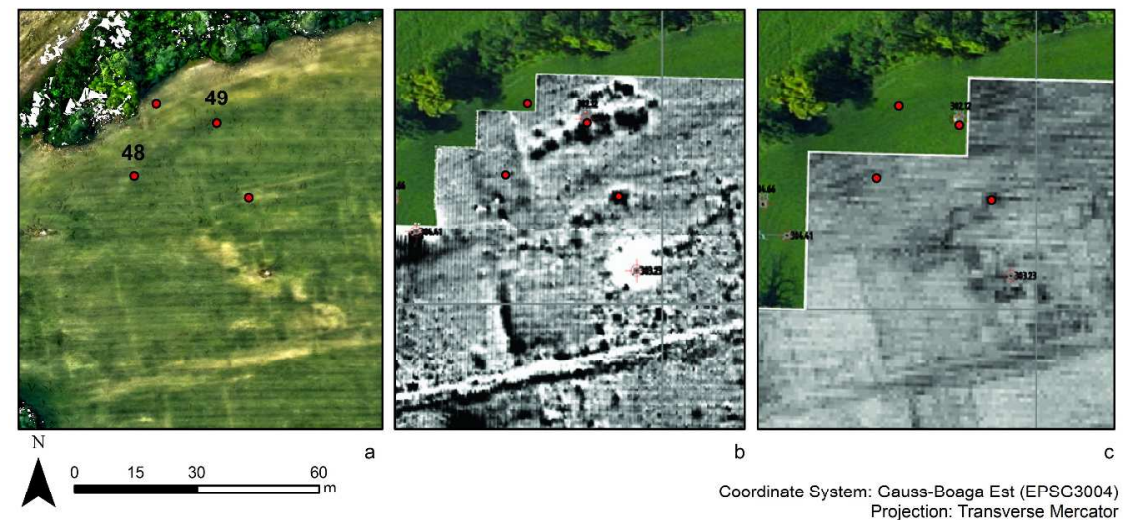

- Hand augerings

Detailed mapping of (a) aerial photography, (b) geomagnetic and (c) geoelectrical resistivity data with hand augering locations in the northwestern part of the intra-mural town area.

$419 \times 295 \mathrm{~mm}(300 \times 300$ DPI $)$ 

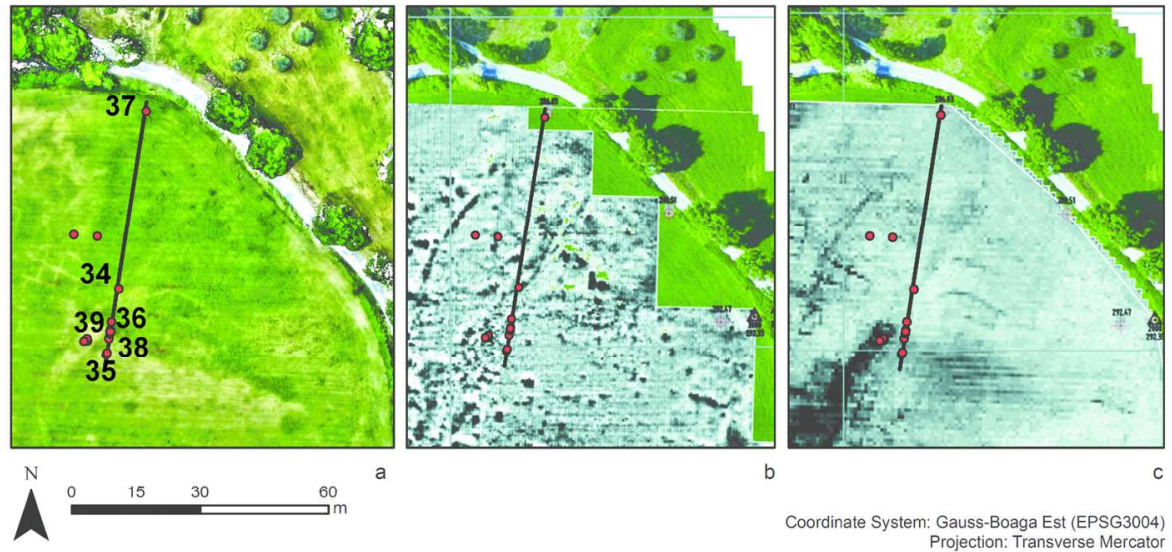

Coordinate System: Gauss-Boaga Est (EPSG3004) Projection: Transverse Mercator
Datum: Monte Mario

- Hand augerings

Augering profile (Figure 12)

Detailed mapping of (a) aerial photography, (b) geomagnetic and (c) geoelectrical resistivity data with hand augering locations in the northeastern part of the intra-mural town area

$147 \times 104 \mathrm{~mm}(300 \times 300 \mathrm{DPI})$ 


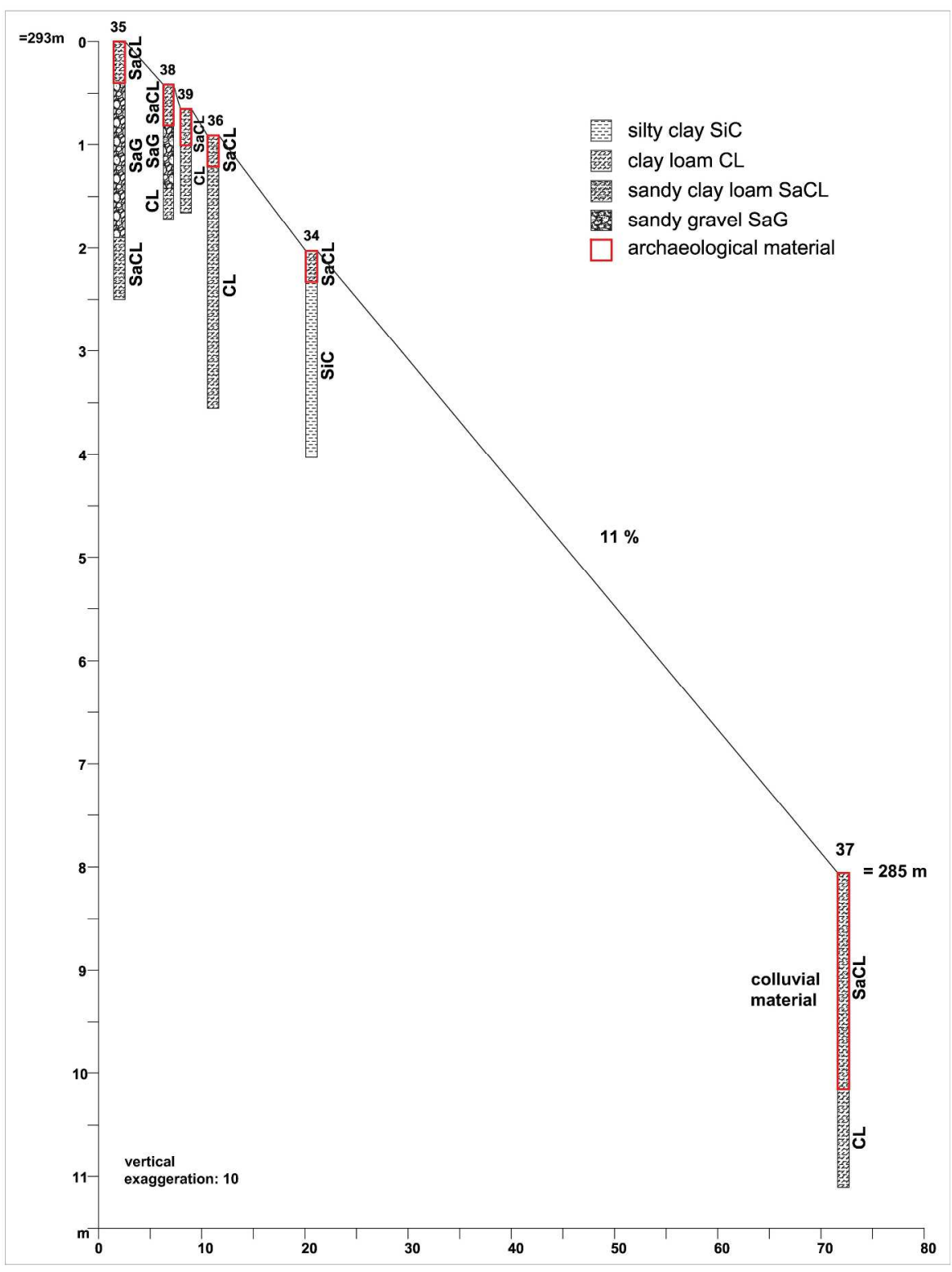

Hand augering profile showing possible landslide $261 \times 344 \mathrm{~mm}$ (300 x $300 \mathrm{DPI})$ 